\title{
Management of consecutive cuts in the production and quality of wintergreen paspalum seeds
}

\author{
Rodrigo Ramos Lopes ${ }^{1}$, Henrique Jaeschke Ost ${ }^{2}$, Cleber Henrique Lopes de Souza², Lucia \\ Brandão Franke ${ }^{1}$
}

\footnotetext{
${ }^{1}$ Universidade Federal do Rio Grande do Sul, Faculdade de Agronomia, Departamento de Plantas Forrageiras e Agrometeorologia, Porto Alegre, RS, Brazil.

${ }^{2}$ Universidade Federal do Rio Grande do Sul, Programa de Pós-graduação em Zootecnia, Porto Alegre, RS, Brazil.
}

\begin{abstract}
The objective of this study was to evaluate the practice of consecutive cuts in the production and quality of Paspalum guenoarum seeds of the "Azulão" ecotype. The experimental design used was in completely randomized blocks with four replications. The treatment included three cuts in succession: zero cut, one cut, two cuts, and three cuts. The variables were: number of total tillers/plant; number of vegetative tillers/plant; number of reproductive tillers/plant; percentage of reproductive tillers; number of racemes/inflorescence; weight of thousand seeds; number of seeds/inflorescence; seed production; forage dry matter; water content of seeds; germination; first germination count; and germination speed index. The largest seed production was obtained with zero cut (850.3, first year and $719.4 \mathrm{~kg} / \mathrm{ha}^{-1}$, second year) and one cut (794.4, first year and $627.3 \mathrm{~kg} / \mathrm{ha}^{-1}$, second year) with no statistical difference between them. The largest germination percentage was seen with the application of zero $(71.0 \%$, first year and $79.3 \%$, second year) and one cut $(69.3 \%$, first year and $75.0 \%$, second year). There was a decrease in the production and quality of the seeds of the second cut, especially during the first year of evaluation. The total tillers, the percentage of tillers that went through the reproductive stage, and the number of reproductive tillers are the variables that are most highly correlated with seed production.
\end{abstract}

Key Words: flowering, germination, Paspalum guenoarum, tillering

\section{Introduction}

The Plicatula group, of the Paspalum genus, is the most important in Brazil and in South America, known for its agronomic characteristics, serving as a feed source for wild and domesticated animals (Meireles et al., 2013). Several studies demonstrate the superiority of this group when compared with genotypes Notata and Livida group (Fachinetto et al., 2012). This is the case of the Paspalum guenoarum species, "Azulão" ecotype, that features high levels of total dry matter production $\left(15995 \mathrm{~kg} / \mathrm{ha}^{-1}\right)$, dry matter from leaves $\left(11218 \mathrm{~kg} / \mathrm{ha}^{-1}\right)$, high digestibility, and cold tolerance (Pereira et al, 2012). Although it demonstrated excellent results regarding the production and quality of the forage, its diffusion is limited by the scarce availability of seeds in the market and their low quality (Pinto, 1982). According to Lopes and Franke (2011a), the production of high-quality seeds is a complex process and is conditioned

Received February 11, 2016 and accepted August 21, 2016.

Corresponding author: lopezhsf@hotmail.com

http://dx.doi.org/10.1590/S1806-92902016001000002

Copyright (C) 2016 Sociedade Brasileira de Zootecnia. This is an Open Access article distributed under the terms of the Creative Commons Attribution License (http://creativecommons.org/licenses/by/4.0/), which permits unrestricted use, distribution, and reproduction in any medium, provided the original work is properly cited. by management practices, environmental factors, and genetic factors.

In crops grown for seed production, the management of forage cuts is justified because it stimulates the formation of high-density tillers, retards and synchronizes the flowering, and aids the harvest process due to the reduction of vegetable mass (Humphreys and Riveros, 1986). Factors such as the number, period, and height of the cuts influence the increase in reproductive tiller concentration, the number of inflorescences, and therefore, the final seed production (Souza, 2001). However, each species has a different reaction to the cuts, which may result in an increase, reduction, or no effect on seed production (PROD) (Jornada et al., 2005). According to Scheffer-Basso et al. (2007), the largest PROD in P. dilatatum was obtained with six cuts before deferral, providing a larger number of inflorescences per plant. Hare et al. (1999) obtained larger PROD in P. atratum applying two cuts. However, the larger number of cuts reduced the production of seeds and the number of inflorescences per area.

Thus, the increase in PROD can be achieved through a careful choice of pasture management (Martiniello, 2008), since early cuts will cause excessive vegetative growth, while late cuts could remove many reproductive meristems (Hare et al., 2007). 
The objective of this study was to evaluate the practice of consecutive cuts in the production and quality of Paspalum guenoarum seeds of the "Azulão" ecotype.

\section{Material and Methods}

The experiment was performed in the agricultural years 2012/2013 and 2013/2014, in the municipality of Eldorado do Sul, Rio Grande do Sul, Brazil. The experimental area was located in the Central Depression region $\left(30^{\circ} 05^{\prime} 52^{\prime \prime} \mathrm{S}, 51^{\circ} 39^{\prime} 08^{\prime \prime} \mathrm{W}\right.$ at an altitude of $\left.32 \mathrm{~m}\right)$. The climate is of the Cfa type, according to the Köppen classification, with an annual rainfall of $1440 \mathrm{~mm}$ (monthly average of $120 \mathrm{~mm}$ ). The average annual temperature was $19.3{ }^{\circ} \mathrm{C}$, with a maximum average of $24.6{ }^{\circ} \mathrm{C}$ in January, and minimum average of $13.8{ }^{\circ} \mathrm{C}$ in June. The climate data during the experimental period was obtained from a meteorological station located $100 \mathrm{~m}$ from the experimental area (Figure 1). The soil is a typic dystrophic Argisoil Rhodustults - PVd (Embrapa, 2013), with the following chemical characteristics: $\mathrm{pH}\left(\mathrm{H}_{2} \mathrm{O}\right), 5.6$; SMP index, 6.1; $\mathrm{P}, 4.5 \mathrm{mg} \mathrm{dm}^{-3}$; $\mathrm{K}, 80 \mathrm{mg} \mathrm{dm}^{-3}$; organic matter (OM), 1.2\%; $\mathrm{Al}^{3+}, 0.0 \mathrm{cmol} \mathrm{dm}^{-3} ; \mathrm{Ca}^{2+}, 2.9 \mathrm{cmol}_{\mathrm{c}} \mathrm{dm}^{-3} ; \mathrm{Mg}^{2+}$, $1.4 \mathrm{cmol}_{\mathrm{c}} \mathrm{dm}^{-3}$; and cation exchange capacity, $8.4 \mathrm{cmol}_{\mathrm{c}}$ $\mathrm{dm}^{-3}$. The experimental area $\left(213.15 \mathrm{~m}^{2}\right)$ was corrected with $2700 \mathrm{~kg} / \mathrm{ha}^{-1}$ of filler-type limestone in July 7, 2012. Then, on October 20, 2012, $300 \mathrm{~kg} / \mathrm{ha}^{-1}$ of 5-20-20 fertilizer was applied, meeting the potassium needs. The recommendation was supplemented with $120 \mathrm{~kg} / \mathrm{ha}^{-1}$ of $\mathrm{N}$ (Urea) and $150 \mathrm{~kg} / \mathrm{ha}^{-1}$ of $\mathrm{P}_{2} \mathrm{O}_{5}$ (Triple Superphosphate), seeking to meet the needs of perennial summer grasses (CQFS-RS/SC, 2004). In the second year of the evaluation, $80 \mathrm{~kg} / \mathrm{ha}^{-1}$ of $\mathrm{P}_{2} \mathrm{O}_{5}$ (replacement dose) was applied.

Planting was carried out, on November 1, 2012, with seedlings kept in a greenhouse during the winter. The experimental units had $7.2 \mathrm{~m}^{2}(3.6 \times 2.0 \mathrm{~m})$ and the plant arrangement was $0.4 \times 0.2 \mathrm{~m}$ (between lines and between plants, respectively). A standardization cut was necessary (December 10, 2012) with a height if $0.10 \mathrm{~m}$ in order to homogenize the canopy, marking the beginning of the trial. Each experimental unit had six plants marked in its center, reserved for evaluations of the components of seed production. The experimental area, after the first year of assessment, remained at rest until the renovation and cleaning cut for the plants $(0.15 \mathrm{~m}$ residual $)$ on September 05,2013 . The experiment was irrigated using five sprinklers that covered the experimental area (the planting and then the cuts).

The experimental design used was completely randomized block design, with measurements repeated over time, and four replications. The treatments consisted of three consecutive cuts: zero cut (control), one cut, two cuts, and three cuts (Table 1), carried out when the canopy height reached $0.4 \mathrm{~m}$, leaving a residue of $0.15 \mathrm{~m}$. The evaluated variables were: total number of tillers/plant (TT) - direct count of all the tillers; number of vegetative tillers/plant (VT) - direct counting of tillers in vegetative stage; number of reproductive tillers/plant (RT) - direct counting of tillers that formed inflorescences; percentage of reproductive tillers (PRT) - proportion of reproductive tillers relative to total tillers; number of racemes/ inflorescence (NRI) - average number of racemes of all
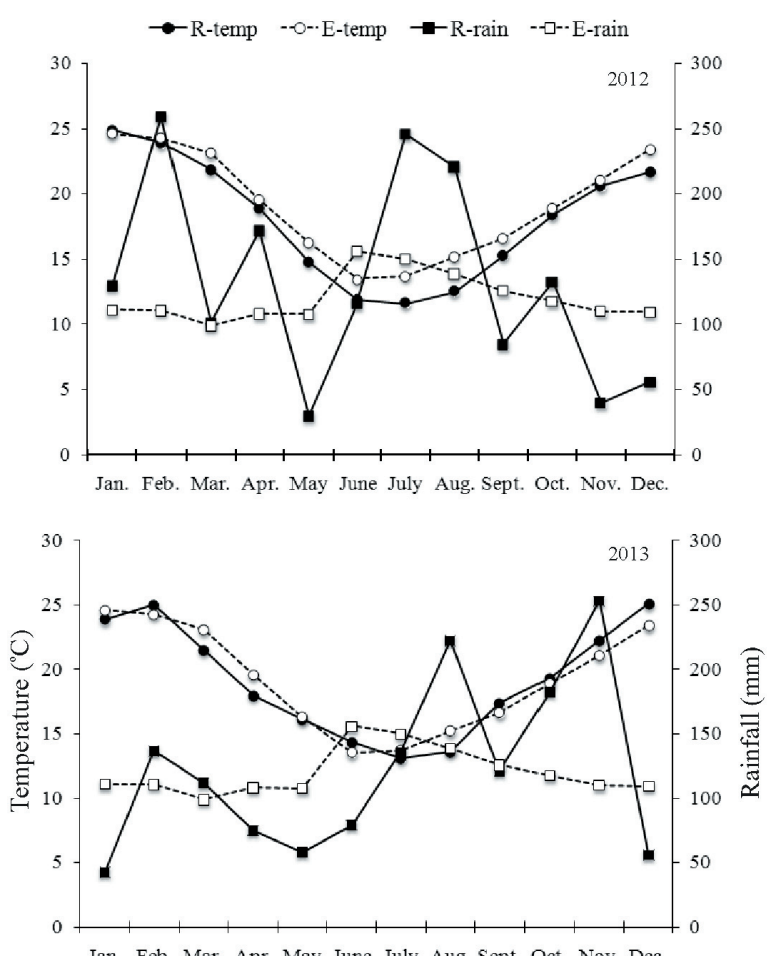

Jeb. Mar Apr. May June July Aug Sept. Oct Nov. Dec.

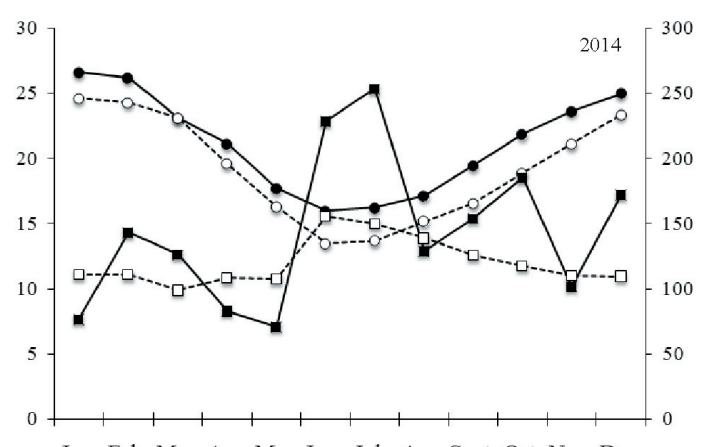

Jan. Feb. Mar. Apr. May June July Aug. Sept. Oct. Nov. Dec.

Period (months)

R-temp - real temperature; E-temp - expected temperature; R-rain - real rainfall; E-rain - expected rainfall

Total rainfall: $2012=1587 \mathrm{~mm} ; 2013=1476 \mathrm{~mm} ; 2014=1725 \mathrm{~mm}$

Figure 1 - Mean monthly temperature and rainfall distribution in the experimental period (Nov. 2012 - Apr. 2014). 
inflorescences harvested at $0.96 \mathrm{~m}^{2}$; weight of thousand seeds (WTS) - average weight of eight subsamples of 100 seeds (pure seeds from $0.96 \mathrm{~m}^{2}$ ) multiplied by 10 , according to rules for seed testing - "RAS" (Brasil, 2009); number of seeds/inflorescence (NSI) - rule of three between the weight of 1,000 seeds and the average weight of seeds/ inflorescence; seed production (PROD) - the harvest was performed when more than $50 \%$ of the inflorescence had a brown coloring and signs of dehiscence of caryopses (The collected inflorescences were dried in an oven with forced ventilation at $30^{\circ} \mathrm{C}$ for $72 \mathrm{~h}$ and manually threshed. The processing was done with the use of sieves to separate the impurities (glume fragments, paleas, lemma, rachis, pedicels, etc.) and a "South Dakota"-type blower for the fractionation of full and empty seeds. After cleaning, pure seeds were weighed from $0.96 \mathrm{~m}^{2}$ and the results were extrapolated to $\mathrm{kg} \mathrm{ha}^{-1}$. Later, the formed lots were stored in a cold chamber); and forage dry matter (DM) - a sample was withdrawn $\left(0.96 \mathrm{~m}^{2}\right)$ in each cutting treatment. The material was dried in a kiln at $65^{\circ} \mathrm{C}$ with forced ventilation for $72 \mathrm{~h}$. The samples were weighed and the results were extrapolated to $\mathrm{kg} \mathrm{DM} \mathrm{ha}^{-1}$.

The water content of seeds was determined by the kiln method at $105 \pm 3{ }^{\circ} \mathrm{C}$ for $24 \mathrm{~h}$, into two subsamples with approximately $4.5 \pm 0.5 \mathrm{~g}^{-1}$ of seeds for each treatment, according to RAS (Brasil, 2009). The purity analysis was performed using $10 \mathrm{~g}$ of seeds from each treatment (processed seeds), separating the sample into three portions (pure seeds, other seeds, and inert material), as prescribed in the RAS (Brasil, 2009), with the data expressed as a percentage. The germination test was performed with four replications of 100 seeds per treatment (from the "pure seed" portion), on "germitest"-type sheets of paper moistened with $\mathrm{KNO}_{3}(0.2 \%)$ solution in an amount equivalent to 2.5 times the mass of the non-hydrated paper, in clear plastic boxes with a lid $(11 \times 11 \times 3.5 \mathrm{~cm})$, followed by seven days of pre-cooling $\left(5-10^{\circ} \mathrm{C}\right)$. After the pre-treatment, the boxes were stored in a germinator under a regime of alternating temperature and light $\left(20{ }^{\circ} \mathrm{C} / 16 \mathrm{~h}\right.$ in the dark and $30{ }^{\circ} \mathrm{C} / 8 \mathrm{~h}$ with light). The light was provided by four fluorescent lamps $(20 \mathrm{~W} ; 1060 \mathrm{~lm})$ located inside the germinator. The results were expressed as percentage of normal seedlings obtained in the twenty-first day (Brasil, 2009). The percentage of dormant seeds was determined at the end of the germination test on the twenty-first day (Brasil, 2009). The first germination count (FGC) was performed considering the number of normal seedlings on the seventh day of the germination test (Brasil, 2009). The germination speed index (GSI) was obtained according to the formula proposed by Maguire (1962), from the germination test itself, computing the number of seeds with root protrusion daily until the twenty-first day.

Variance analysis and $\mathrm{F}$ test were performed using PROC MIXED of SAS (Statistical Analysis System, version 9.1.3). It adopted the standard covariance structure for random effects, variance components, using the REML estimate. The averages were calculated using the LSMEANS procedure and their comparison was done using the Tukey test $(\mathrm{P}<0.05)$. The residual correlation matrix of the studied variables was done using the PROC CORR (Statistical Analysis System, version 9.1.3). The data were subjected to tests of normality and homogeneity of variance, which did not indicate the need for transformation.

\section{Results and Discussion}

Through the analysis of variance of the TT, it was found that there was no significance $(\mathrm{P}>0.05)$ in the cuts $\times$ years interaction, with significance occurring $(\mathrm{P}<0.05)$ only for the isolated effects of cuts and years (Table 2 ). The values observed in the TT was decreasing due to the number of cuts applied. The highest values were found in the uncut treatment (52.2 tillers/plant), not statistically different from the treatment with one cut (48.8 tillers/plant). When two and

Table 1 - Cutting dates and harvest date of Paspalum guenoarum, "Azulão" ecotype, seeds

\begin{tabular}{lccccc}
\hline Cut & & Cut 1 & Cut 2 & Harvest \\
\hline & & & $2012 / 2013$ & & \\
Standardization cutting & Dec 10,2012 & - & & - & - \\
Zero cut (control) & - & - & - & - \\
One cut & - & Jan 07, 2013 & Mar 12, 2013 & - \\
Two cuts & - & Jan 07, 2013 & Jan 25, 2013 & - \\
Three cuts & - & Jan 07, 2013 & Jan 25, 2013 & Feb 20, 2013
\end{tabular}

Standardization cutting

Zero cut (control)

One cut

Two cuts

Three cuts
Sept. 05, 2013

-
-
-
-

-
-
Nov 26, 2013
Nov 26, 2013
Nov 26, 2013

$2013 / 2014$

$\begin{array}{ccc}- & - & - \\ - & - & \text { Feb 26, 2014 } \\ - & - & \text { Feb 26, 2014 } \\ \text { Dec 17, 2013 } & - & \text { Mar 06, 2014 } \\ \text { Dec 17, 2013 } & \text { Jan 07, 2014 } & \text { Mar 26, 2014 }\end{array}$

R. Bras. Zootec., 45(10):587-595, 2016 
three cuts were applied, there was a significant difference compared with previous treatments, observing the lowest values in the treatment with three cuts (34.7 tillers/plant). There was a significant variation between years $(\mathrm{P}<0.05)$, in which, in the first year, there was a higher number of total tillers/plant (Table 2). According to Moore et al. (2004), in formed pastures, the tiller populations adjust to the limits set by the genotype in response to stimuli resulting from climatic variations, the degree of competition between them, and management practices.

Both the main effects (cuts and years) as well as the interaction between the factors (cuts $\times$ years) significantly influenced $(\mathrm{P}<00.5)$ the VT (Table 2). In the first year, the higher amount of vegetative tillers/plant was observed in the treatment of three cuts (36.6 vegetative tillers per plant), differing from the treatments with zero cut, one cut, and two cuts (Table 2). The plasticity of a production component can be inversely related to the cost/benefit associated therewith (Bloom et al., 1985). This means that the plant would adapt to imposed changes (three consecutive cuts) by the preferential production of components involving low cost or that provide net benefits. In this case, tillering has a high initial cost, but adds to the ability of the plant to survive and capture resources (Sadras and Slafer, 2012). In the second year, there were no significant differences between the levels of the cutting effects.

Table 2 - Mean values of the evaluated variables of Paspalum guenoarum, “Azulão" ecotype, depending on the consecutive cuts, in two years

\begin{tabular}{|c|c|c|c|c|c|c|}
\hline Cut & $2012 / 2013$ & $2013 / 2014$ & Mean & $2012 / 2013$ & $2013 / 2014$ & Mean \\
\hline & \multicolumn{3}{|c|}{ TT (number.plant) } & \multicolumn{3}{|c|}{ VT (number.plant) } \\
\hline Zero cut & 56.0 & 48.3 & $52.2 \mathrm{a}$ & $\mathrm{A} 24.5 \mathrm{~b}$ & B15.5a & 20.0 \\
\hline One cut & 50.0 & 47.5 & $48.8 \mathrm{a}$ & $\mathrm{A} 20.0 \mathrm{~b}$ & A13.8a & 16.9 \\
\hline Three cuts & 39.5 & 29.8 & $34.7 \mathrm{c}$ & A36.3a & B18.3a & 27.3 \\
\hline Mean & $47.5 \mathrm{~A}$ & $41.0 \mathrm{~B}$ & - & 25.1 & 15.3 & - \\
\hline F (cuts) & \multicolumn{3}{|c|}{$41.25^{* *}$} & \multicolumn{2}{|c|}{$30.92 * *$} & \\
\hline
\end{tabular}

\begin{tabular}{|c|c|c|c|}
\hline & & number.p & \\
\hline Zero cut & A31.8a & A $32.8 \mathrm{a}$ & 32.3 \\
\hline One cut & A $30.0 \mathrm{ab}$ & A $33.8 \mathrm{a}$ & 31.9 \\
\hline Two cuts & $\mathrm{A} 25.0 \mathrm{~b}$ & $\mathrm{~A} 24.8 \mathrm{~b}$ & 24.9 \\
\hline Three cuts & B3.3c & $\mathrm{A} 11.5 \mathrm{c}$ & 7.4 \\
\hline Mean & 22.5 & 25.7 & - \\
\hline F (cuts) & \multicolumn{2}{|c|}{$259.39 * *$} & \\
\hline F (years) & \multicolumn{2}{|c|}{$19.42 * *$} & \\
\hline $\mathrm{F}($ cuts $\times$ years $)$ & \multicolumn{2}{|c|}{$6.78 *$} & \\
\hline
\end{tabular}

\begin{tabular}{|c|c|c|}
\hline \multirow[t]{2}{*}{$\mathrm{F}($ cuts $\times$ years $)$} & \multicolumn{2}{|r|}{$6.78^{*}$} \\
\hline & & NRI (number.inflorescence) \\
\hline Zero cut & A4.7a & A5.0a \\
\hline One cut & A4.7a & A $4.3 \mathrm{a}$ \\
\hline Two cuts & A $4.4 \mathrm{a}$ & A $4.3 \mathrm{a}$ \\
\hline Three cuts & A $4.4 \mathrm{a}$ & $\mathrm{B} 3.2 \mathrm{~b}$ \\
\hline Mean & 4.6 & 4.2 \\
\hline F (cuts) & \multicolumn{2}{|r|}{$17.52 * *$} \\
\hline F (years) & \multicolumn{2}{|r|}{$14.11 * *$} \\
\hline $\mathrm{F}($ cuts $\times$ years $)$ & \multicolumn{2}{|r|}{$9.10 * *$} \\
\hline & \multicolumn{2}{|r|}{ WTS $\left(\mathrm{g}^{-1}\right)$} \\
\hline Zero cut & $\mathrm{A} 3.2 \mathrm{~b}$ & A3.1a \\
\hline One cut & $\mathrm{A} 3.5 \mathrm{a}$ & B2.9ab \\
\hline Two cuts & A3.4ab & $\mathrm{B} 2.8 \mathrm{~b}$ \\
\hline Three cuts & $\mathrm{A} 3.1 \mathrm{~b}$ & $\mathrm{~B} 2.8 \mathrm{~b}$ \\
\hline Mean & 3.3 & 2.9 \\
\hline $\mathrm{F}$ (cuts) & \multicolumn{2}{|r|}{$8.90 * *$} \\
\hline F (years) & \multicolumn{2}{|r|}{$117.67 * *$} \\
\hline $\mathrm{F}($ cuts $\times$ years $)$ & \multicolumn{2}{|r|}{$10.49^{* *}$} \\
\hline
\end{tabular}

\begin{tabular}{|c|c|c|}
\hline \multicolumn{3}{|c|}{ PRT (\%) } \\
\hline B56.3a & A67.8a & 62.1 \\
\hline B59.5a & A71.3a & 65.4 \\
\hline B56.3a & A64.8a & 60.1 \\
\hline B7.5b & $\mathrm{A} 38.8 \mathrm{~b}$ & 23.2 \\
\hline 44.9 & 60.6 & - \\
\hline \multicolumn{3}{|c|}{$292.62 * *$} \\
\hline \multicolumn{3}{|c|}{$227.34 * *$} \\
\hline & & \\
\hline
\end{tabular}

TT - number of total tillers/plant; VT - number of vegetative tillers/plant; RT - number of reproductive tillers/plant; PRT - percentage of reproductive tillers; NRI - number of racemes/inflorescence; NSI - number of seeds/inflorescence; WTS - weight of a thousand seeds; PROD - seed production.

Values followed by the same lowercase letter in columns and uppercase letter in the rows do not differ $(\mathrm{P}>0.05)$ by the Tukey test

** and * Significant at $\mathrm{P}<0.01$ and $\mathrm{P}<0.05$, respectively, by the $\mathrm{F}$ test.

ns - not significant. 
The variance analysis in the RT proved significant differences $(\mathrm{P}<0.05)$ between cuts and years and also a significant effect for the cuts $\times$ years interaction (Table 2 ). In general, the effect of cutting presented similar values for reproductive tillers/plant among the levels of effect for years, with the exception of the treatment with three cuts. The largest values were found in the treatments with zero cut and one cut, with no statistical difference between them regarding years. Starting with the first cut, there was a gradual reduction in the RT in both years, noting the smaller values in the three-cut treatment (3.3 and 11.5 reproductive tillers/plant, respectively). The application of consecutive cuts, added to the date of the last cut, reached many tillers that had already begun the elongation of the stems, elevating the meristems. According to Martiniello and Silva (2011), the cutting, especially after the initiation of flower differentiation, reduces the leaf area, reserves substances, and eliminates flower primordia. The knowledge of the morphological position of the meristems is fundamental to the management of pasture cuts, because it reduces the stress of regrowth, increases biomass (tillering), and hence, crop seed production (Martiniello, 2008).

The main effects (cuts and year) and their interaction (cuts $\times$ years) had a significant effect $(\mathrm{P}<0.05)$ on the PRT relative to the total amount of tillers (Table 2). An analysis of this variable provides a view of the tiller rate that moved on to the reproductive stage in relation to total tillers produced by the plant. The highest rates were noted in the zero-, one-, and two-cut treatments, with no difference between them $(\mathrm{P}>0.05)$. Considering the results from the number of reproductive tillers and the PRT relative to the total tillers (Table 2), it appears that there was no interruption to flowering induction, including the treatment with three cuts. The $P$. genoarum species has no references in the literature regarding photoperiodism; however, observations during the experiment showed that the flowering period of the material is long, with little arising photoperiodic sensibility. According to West and Pitman (2001), the plants in the tropics and subtropics are short-day or day-neutral. In P. plicatulum and P. atratum, short days are favorable for inducing the expression of reproductive processes, i.e., when the duration of night is equal or greater than a specific value, called the critical photoperiod (Chadhokar and Humphreys, 1973; Hare et al., 2001). However, for $P$. dilatatum, the flowering does not depend on the photoperiod, but occurs in response to other stimuli (water availability and temperature) (Skerman and Riveros, 1992).

The analysis of variance in the NRI showed significance $(\mathrm{P}<0.05)$ in the cuts $\times$ years interaction and the isolated effects of cutting and years (Table 2). There was no significant difference in this component during the first year of evaluation, remaining stable due to the applied cuts. However, during the second year, when three cuts were applied, there was a decrease in the NRI (Table 2). Carámbula (1981) states that increasing the number of cuts tends to reduce this variable, possibly due to the elimination of the first inflorescences, recognized by the literature as more productive than those that appear later. Chadhokar and Humphreys (1973) also observed a reduction in the number of racemes in the inflorescences of $P$. plicatulum issued later.

A significant effect was observed $(\mathrm{P}<0.05)$ in the cuts $x$ years interaction and in the isolated effects of cuts and years $(\mathrm{P}<0.05)$ in the WTS (Table 2$)$. In the first year, the highest values were found when one and two cuts were applied (3.5 and $3.4 \mathrm{~g}^{-1}$, respectively). In the second year, as the number of cuts increased, there was a reduction in the WTS. Treatments of zero and one cut had the highest values (3.1 and $2.9 \mathrm{~g}^{-1}$, respectively), statistically surpassing the treatments of two and three cuts $\left(2.8 \mathrm{~g}^{-1}\right)$. The most intense defoliation regimes directly affect the final mass of seeds due to competition for the reserves and photoassimilates in the leaves, stems, and young inflorescences (Hare et al., 2007; Martiniello and Silva, 2011; Awad et al., 2013). The nutrient competition can also be influenced by the tiller hierarchy, i.e., tillers of smaller orders form heavier seeds since they receive more assimilates. In Panicum maximum, the translocation of assimilates from the main tiller to the younger primary tiller was lower $(6.5 \%)$ than from the primary tiller to the main tiller $(14 \%)$ due to the greater mass of the lower-order tiller (Carvalho et al., 2006).

The NSI was affected by the number of cuts applied, the years, and also by the cuts $\times$ years interaction $(\mathrm{P}<0.05)$ (Table 2). The highest values seen during the first year were in the zero treatment and one cut ( 82.8 and 77.3 seeds/inflorescence, respectively) and less when two and three cuts were applied (49.4 and 37.2 seeds/inflorescence, respectively). The behavior of the NSI during the second year was greater than the first, showing a growing trend in relation to the treatments, i.e., the increase in the number of cuts increased the NSI (Table 2). In forage grass species, most of the components connected to the production of seeds is in the inflorescence and their reproductive tillers. The analyses of the means for the variables number of seeds/ inflorescence, number of racemes/inflorescence, weight of 1,000 seeds, and reproductive tillers (Table 2) revealed that the increase of one variable causes the decrease in the other, due to the plasticity, or compensation capacity of the plant, in response to management (Nakagawa, 2014). That is, the 
components that arise after the cuts undergo a regulation by the plant in order to adapt these structures (tillers, inflorescences, racemes, and weight of seed) to a new use condition for the reserve substances and photoassimilates available (source-sink ratio) (Sadras and Slafer, 2012).

The values obtained in the variance analysis (Table 2) show that the production of seed was affected by cutting management and the cuts $\times$ years interaction $(\mathrm{P}<0.05)$. In both years, PROD was greater when plants were not cut (850.3 and $784.9 \mathrm{~kg} / \mathrm{ha}^{-1}$, respectively), although not statistically different when cut once (794.4 and $627.3 \mathrm{~kg} / \mathrm{ha}^{-1}$, respectively). As of the completion of the second cut, in the first year, there was a considerable drop in the production of seeds for the treatments with two and three cuts (336.2 and $21.9 \mathrm{~kg} / \mathrm{ha}^{-1}$, respectively) in comparison with the others. In the second year of the evaluation, the treatments of two and three cuts were not statistically different (407.2 and $336.7 \mathrm{~kg} / \mathrm{ha}^{-1}$, respectively). Regarding the analysis between years (Table 2), the behavior of PROD showed the same trend, with the exception of the treatment with three cuts. This is due to the dates when the cuts were implemented, which were different than in the first year. In the first year, when the experiment was carried out, the cuts were applied later than in the second year. According to Jornada et al. (2005), the late cuts in relation to the cycle of forage grasses can have negative effects on productivity of seeds, possibly by reducing the photosynthetic area and eliminating reproductive parts of the tillers.

The values of PROD found in this study are higher than those found in the literature that often cites the species $P$. notatum cv. Pensacola, widespread in Brazil. Gates and Burton (1998), in a Pensacola-PROD experiment, as a result of fertilization, achieved the production of $514 \mathrm{~kg} / \mathrm{ha}^{-1}$ of seeds with the application of $224 \mathrm{~kg} \mathrm{~N} / \mathrm{ha}^{-1}, 25 \mathrm{~kg} \mathrm{P} / \mathrm{ha}^{-1}$, and $47 \mathrm{~kg} \mathrm{~K} / \mathrm{ha}^{-1}$. No benefit was achieved above $224 \mathrm{~kg}$ $\mathrm{N} / \mathrm{ha}^{-1}$. However, it should be noted that the ecotype studied underwent no selection and that this study did not test the effects of fertilizer doses on seed production.

No interactions were observed between the effects of cuts and years, or a year effect for the total dry matter (Table 3). Only the isolated effect of the cuts was significant $(\mathrm{P}<0.05)$ in total harvested forage. The treatment with three cuts showed the highest total dry matter value with $6684.5 \mathrm{~kg} \mathrm{DM} / \mathrm{ha}^{-1}$ (Table 3).

At the end of the track and cleaning process of the seeds harvested in the field, the lots formed by the four treatments showed no significant differences $(\mathrm{P}>0.05)$ in moisture content but were statistically different $(\mathrm{P}>0.05)$ between years (Table 4$)$. In the purity analysis, the only effect that was significant $(\mathrm{P}<0.05)$ was the cuts and there was no significance between years and the cuts $\times$ years interaction (Table 4). The values are within the standards for the production of P. guenoarum seeds (MAPA, 2008).

The germination of $P$. guenoarum seeds was affected by the number of cuts, the years, and the cuts $\times$ years interaction $(\mathrm{P}<0.05)$ (Table 4). In the first year, the zero and one cut treatment had the highest germination values (71.0 and $69.3 \%$, respectively), differing significantly from the treatments with two $(36.5 \%)$ and three cuts $(26.8 \%)$ (Table 4). In the second year, the treatments with zero and one cut had the highest germination values (79.3 and $75.0 \%$, respectively), statistically differing from the twoand three-cut treatments (63.3 and $60.0 \%$, respectively). Possibly, the factor responsible for the low quality of seeds in the two- and three-cut treatments in the first year was the elimination of the first reproductive tillers, considered by many authors as responsible for much of the production and quality of seed lots (Carámbula, 1981; Humphreys and Riveros, 1986).

The average percentage of dormant seeds was significant only for the purpose of cutting $(\mathrm{P}<0.05)$ (Table 4). The dates of harvesting, drying, and processing procedures were different due to the cutting treatments, resulting in unequal storage periods. This may explain the variation in the intensity of dormancy between lots, because the germination test was done at the same time for all treatments (three months after the harvest of the zerocut treatment). The expression of dormancy is linked to physiological causes in the newly harvested seeds, which are progressively suppressed with the storage time (Munhoz et al., 2009). According to Batista and Godoy (1998), the lower percentage of dormancy in P. guenoarum seeds was obtained after 90 days of storage.

It is noteworthy that the results obtained in this work, with the exception of two- and three-cut treatments in the

Table 3 - Total dry matter production of Paspalum guenoarum, "Azulão" ecotype, depending on the consecutive cuts, in two years

\begin{tabular}{lccc}
\hline \multirow{2}{*}{ Cut } & \multicolumn{2}{c}{ Total dry matter $\left(\mathrm{kg} \cdot \mathrm{ha}^{-1}\right)$} & \multirow{2}{*}{ Mean } \\
\cline { 2 - 3 } & $2012 / 2013$ & $2013 / 2014$ & \\
\hline Zero cut (control) & 0 & 0 & $0 \mathrm{~d}$ \\
One cut & 2241 & 2252 & $2247 \mathrm{c}$ \\
Two cuts & 4436 & 4641 & $4539 \mathrm{~b}$ \\
Three cuts & 6671 & 6699 & $6685 \mathrm{a}$ \\
Mean & $3337 \mathrm{~A}$ & $3398 \mathrm{~A}$ & - \\
F (cuts) & & & \\
F (years) & & $541.59 * *$ \\
F (cuts $\times$ years) & & $0.24 \mathrm{~ns}$ & \\
\hline
\end{tabular}

Values followed by the same lowercase letter in columns and uppercase letter in the rows do not differ $(\mathrm{P}>0.05)$ by the Tukey test.

$* *$ and * Significant $\mathrm{P}<0.01$ and $\mathrm{P}<0.05$, respectively, by the $\mathrm{F}$ test. ns - not significant. 
first year, are within the realm of standard commercial forage grass seed (60\% germination) (MAPA, 2008). In Brazil, it is estimated that $60 \%$ of the production of forage grass seeds are of Urochloa brizantha (Euclides et al., 2010); however, in a study that aimed to evaluate the physical and physiological quality of those seeds in the 2006, 2007, and 2008 harvests, Ohlson et al. (2009) found that $36-100 \%$ of the samples analyzed (depending on the harvest and cultivar) were not within the standards of physical and physiological quality established for commercial seed.

The first count of germination and germination speed index were influenced by the application of consecutive cuts, year planted, and the cuts $\times$ years interaction $(\mathrm{P}<0.05)$ (Table 4). These two variables showed the same behavior for germination and the decrease of the vigor of the seeds

Table 4 - Mean values of water content of seeds (WCS), purity testing (P), germination (G), dormant seeds (D), first germination count (FGC), and germination speed index (GSI) of Paspalum guenoarum, "Azulão" ecotype, depending on the consecutive cuts, in two years

\begin{tabular}{|c|c|c|c|c|c|c|}
\hline Cut & $2012 / 2013$ & $2013 / 2014$ & Mean & $2012 / 2013$ & $2013 / 2014$ & Mean \\
\hline & & WCS (\%) & & & $\mathrm{P}(\%)$ & \\
\hline Zero cut & 13.8 & 13.7 & 13.8 & 98.4 & 98.4 & $98.4 \mathrm{a}$ \\
\hline One cut & 14.0 & 13.7 & 13.9 & 98.4 & 98.3 & $98.4 \mathrm{a}$ \\
\hline Two cuts & 13.9 & 13.9 & 13.9 & 97.5 & 97.6 & $97.6 \mathrm{~b}$ \\
\hline Three cuts & 13.9 & 13.8 & 13.9 & 97.4 & 97.5 & $97.5 \mathrm{~b}$ \\
\hline Mean & $13.9 \mathrm{~A}$ & $13.7 \mathrm{~B}$ & - & 97.9 & 98.0 & - \\
\hline F (cuts) & \multicolumn{2}{|c|}{$0.99 \mathrm{~ns}$} & \multicolumn{4}{|c|}{$40.43 * *$} \\
\hline F (years) & \multicolumn{2}{|c|}{$6.27 *$} & \multicolumn{4}{|c|}{$0.10 \mathrm{~ns}$} \\
\hline \multirow[t]{2}{*}{ F (cuts $\times$ years $)$} & \multicolumn{2}{|c|}{$0.06 \mathrm{~ns}$} & \multicolumn{4}{|c|}{$0.31 \mathrm{~ns}$} \\
\hline & \multicolumn{3}{|c|}{$\mathrm{G}(\%)$} & \multicolumn{3}{|c|}{$\mathrm{D}(\%)$} \\
\hline Zero cut & B71.0a & A79.3a & 75.2 & 4.5 & 5.4 & $5.0 \mathrm{~b}$ \\
\hline One cut & B69.3a & A75.0a & 72.2 & 5.0 & 4.8 & $4.9 \mathrm{~b}$ \\
\hline Two cuts & B $36.5 b$ & A63.3b & 49.9 & 8.8 & 8.9 & $8.9 \mathrm{a}$ \\
\hline Three cuts & $\mathrm{B} 26.8 \mathrm{c}$ & A $63.0 \mathrm{~b}$ & 44.9 & 9.4 & 9.3 & $9.4 \mathrm{a}$ \\
\hline Mean & 50.9 & 70.1 & - & 6.9 & 7.1 & - \\
\hline F (cuts) & \multicolumn{2}{|c|}{$428.6^{* *}$} & \multicolumn{4}{|c|}{$40.49 * *$} \\
\hline F (years) & \multicolumn{2}{|c|}{$674.8^{* *}$} & \multicolumn{4}{|c|}{$0.69 \mathrm{~ns}$} \\
\hline \multirow[t]{2}{*}{ F (cuts $\times$ years $)$} & \multicolumn{2}{|c|}{$98.42 * *$} & \multicolumn{4}{|c|}{$0.99 \mathrm{~ns}$} \\
\hline & \multicolumn{3}{|c|}{ FGC (\%) } & \multicolumn{3}{|c|}{ GSI } \\
\hline Zero cut & B58.8a & A69.0a & 63.9 & B14.2a & A19.3a & 16.8 \\
\hline One cut & A $55.5 \mathrm{a}$ & A63.8a & 59.7 & B13.2a & A18.4a & 15.8 \\
\hline Two cuts & $\mathrm{B} 24.8 \mathrm{~b}$ & $\mathrm{~A} 52.5 \mathrm{~b}$ & 38.7 & $\mathrm{~B} 6.1 \mathrm{~b}$ & A $15.1 \mathrm{~b}$ & 10.6 \\
\hline Three cuts & $\mathrm{B} 14.8 \mathrm{c}$ & A $51.5 \mathrm{~b}$ & 33.2 & $\mathrm{~B} 4.2 \mathrm{c}$ & A $14.9 \mathrm{~b}$ & 9.6 \\
\hline Mean & 38.4 & 59.2 & - & 9.4 & 16.9 & - \\
\hline F (cuts) & \multicolumn{2}{|c|}{$129.18 * *$} & \multicolumn{4}{|c|}{$425.19 * *$} \\
\hline F (years) & \multicolumn{2}{|c|}{$286.05 * *$} & \multicolumn{4}{|c|}{$1818.04 * *$} \\
\hline F (cuts $\times$ years $)$ & \multicolumn{2}{|c|}{$31.64 * *$} & \multicolumn{4}{|c|}{$64.71 * *$} \\
\hline
\end{tabular}

Values followed by the same lowercase letter in columns and uppercase letter in the rows do not differ $(\mathrm{P}>0.05)$ by the Tukey test.

$* *$ and * Significant at $\mathrm{P}<0.01$ and $\mathrm{P}<0.05$, respectively, by the $\mathrm{F}$ test.

ns - not significant.

Table 5 - Correlation coefficient values between the evaluated variables of Paspalum guenoarum, "Azulão" ecotype, depending on the consecutive cuts, in two years

\begin{tabular}{|c|c|c|c|c|c|c|c|c|}
\hline & TT & VT & RT & PRT & NRI & NSI & WTS & PROD \\
\hline TT & - & $-0.22 \mathrm{~ns}$ & $0.86^{* *}$ & $0.68 * *$ & $0.61 * *$ & $-0.01 \mathrm{~ns}$ & $0.41^{*}$ & $0.81 * *$ \\
\hline VT & & - & $-0.69 * *$ & $-0.86^{* *}$ & $-0.25 \mathrm{~ns}$ & $-0.17 \mathrm{~ns}$ & $-0.51^{* *}$ & $-0.49^{* *}$ \\
\hline RT & & & - & $0.95 * *$ & $0.58 * *$ & $0.08 \mathrm{~ns}$ & $0.57 * *$ & $0.86^{* *}$ \\
\hline PRT & & & & - & $0.50 * *$ & $0.10 \mathrm{~ns}$ & $0.58 * *$ & $0.76^{* *}$ \\
\hline NRI & & & & & - & $-0.47 * *$ & $0.50 * *$ & $0.48 * *$ \\
\hline NSI & & & & & & - & $-0.24 \mathrm{~ns}$ & $0.38 *$ \\
\hline WTS & & & & & & & - & $0.43^{*}$ \\
\hline PROD & & & & & & & & - \\
\hline
\end{tabular}

TT - number of total tillers/plant; VT - number of vegetative tillers/plant; RT - number of reproductive tillers/plant; PRT - percentage of reproductive tillers; NRI - number of racemes/inflorescence; NSI - number of seeds/inflorescence; WTS - weight of a thousand seeds; PROD - seed production.

** and * Significant at $\mathrm{P}<0.01$ and $\mathrm{P}<0.05$, respectively, by the $\mathrm{F}$ test.

ns - not significant. 
can be explained in the same way as the as the germination variable.

Studies evaluating the production of seeds of a certain kind of species always seek, in a way, to identify, quantify, and correlate the production components with the production itself (Lopes and Franke, 2011a). Through correlation analysis, we note that some variables presented significant correlations, both positive and negative, with PROD in $P$. guenoarum, demonstrating that they somehow influenced the expression of this variable (Table 5).

The variable most highly correlated with the production of seeds is the RT $(r=0.86)$. The number of reproductive tillers is one of the most important and crucial components of forage grass seed productivity and, therefore, the management should be focused on favoring this component. The strong association of this component with seed yield was proven in Urochloa (Quadros et al., 2010), Paspalum urvillei (Lopes and Franke, 2011a), Paspalum notatum (Lopes and Franke, 2011b), and Panicum maximum (Canto et al., 2012) and even serves as an indicator for breeding programs that seek to produce seeds of forage species (Biligetu et al., 2012). According to Souza (2001), the increased production of reproductive tiller requires a greater number of inflorescences and, therefore, higher final seed yield.

Other interesting correlations were found to be significant, for example, $\mathrm{VT} \times \mathrm{PROD}$ and the PRT relative to $\mathrm{TT} \times \mathrm{VT}$, whose coefficients were negative $(\mathrm{r}=-0.49$ and $\mathrm{r}=-0.86$, respectively) (Table 5). The tillering in perennial grasses occurs continuously throughout the life cycle of the plant; however, it is variable regarding the intensity of tiller appearance, due to the growing season. The transition from the vegetative to the reproductive stage is not synchronized because, in the same "mother" plant, there is a hierarchy among the tillers that scales the emergence of the inflorescences. Soon, in the same plant, there is assimilated partition between the tillers in elongation (reproductive) and those younger in their development (vegetative), negatively influencing PROD (Lopes and Franke, 2011b).

Seed production per area represents the integration of individual production for all the tillers that make up the pasture (Lopes and Franke, 2011b). The pattern of tillers per plant and how it is altered under stress conditions (cuts) needs to be known. Knowledge regarding the ability of the compensatory effect of the plant between the components of PROD is of fundamental importance to be able to recommend differentiated management techniques to better exploit the production of seeds.

\section{Conclusions}

The management of consecutive cuts affects the production and quality of the Paspalum guenoarum "Azulão" ecotype seeds. The largest production of seeds is obtained when the plants are not cut or when they are cut only once. The total tillers, the percentage of tillers that went through the reproductive stage, and the number of reproductive tillers are the variables that are most highly correlated with seed production.

\section{Acknowledgments}

To Coordenação de Aperfeiçoamento de Pessoal de Nível Superior (CAPES, process 007488/2011-35) for the financial support and scholarship granted.

\section{References}

Awad, A.; Hafiz, S.; Hammada, M. S.; El-Nouby, A. and El-Hendawy, S. 2013. Grain yield production of Sudan grass (Sorghum sudanense (Piper) Stapf) as influenced by cutting numbers, potassium rates, and intrarow spacing in a semiarid environment. Turkish Journal of Agriculture and Forestry 37:657-664.

Batista, L. A. R. and Godoy, R. 1998. Capacidade de produção de sementes em acessos do gênero Paspalum. Revista Brasileira de Zootecnia 27:841-847.

Biligetu, B.; Schellenberg, M. P.; Mcleod, J. G. and Wang, Z. 2012. Seed yield variation in plains rough fescue (Festuca hallii (Vasey) Piper) populations and its relation with phenotypic characteristics and environmental factors. Grass and Forage Science 68:589-595.

Bloom, A. J.; Chapin, F. S. I. and Mooney, H. A. 1985. Resource limitation in plants an economic analogy. Annual Review of Ecology, Evolution and Systematics 16:363-392.

Brasil. Ministério da Agricultura, Pecuária e Abastecimento. 2009. Regras para análise de sementes. Secretaria de Defesa Agropecuária. Brasília, DF.

Canto, M. V.; Barth Neto, A.; Pancera Júnior, E. J., Gasparino, E. and Boleta, V. S. 2012. Produção e qualidade de sementes do capim-mombaça em função da adubação nitrogenada. Bragantia $71: 430-437$.

Carámbula, M. 1981. Producción de semillas de plantas forrajeras. Hemisferio Sur, Montevideo.

Carvalho, D. D.; Irving, L. J.; Carnevalli, R. A.; Hodgson, J. and Mattew, C. 2006. Distribution of current photosynthate in two guinea grass cultivars. Journal Experimental Botany 57:2015-2024.

Chadhokar, P. A. and Humphreys, L. R. 1973. Influence of time and level of urea application on seed production of Paspalum plicatulum at Mt. Cotton, south-eastern Queensland. Australian Journal of Experimental Agriculture and Animal Husbandry 13:275-283.

CQFS-RS/SC - Comissão de Química e Fertilidade do Solo. 2004. Manual de adubação e de calagem para os estados do Rio Grande do Sul e Santa Catarina. 10.ed. Sociedade Brasileira de Ciência do Solo/Núcleo Regional Sul, Porto Alegre, RS.

Embrapa - Empresa Brasileira de Pesquisa Agropecuária. 2013. Sistema Brasileiro de Classificação de Solos. 3.ed. CNPS, Rio de Janeiro, RJ. 
Euclides, V. P. B.; Valle, C. B.; Macedo, M. C. M.; Almeida, R. G.; Montagner, D. B. and Barbosa, R. A. 2010. Brazilian scientific progress in pasture research during the first decade of XXI century. Revista Brasileira de Zootecnia 39:151-168.

Fachinetto, J. M.; Schneider, R.; Hubber, K. G. da C. and Dall'Agnol, M. 2012. Avaliação agronômica e análise da persistência em uma coleção de acessos de Paspalum notatum Flügge (Poaceae). Revista Brasileira de Ciências Agrárias 7:189-195.

Gates, R. N. and Burton, G. W. 1998. Seed yield and seed quality response of Pensacola and improved Bahiagrasses to fertilization. Agronomy Journal 90:607-611.

Hare, M. D.; Tatsapong, P. and Saipraset, R. 2007. Seed productin of two brachiaria hybrid cultivars in north-east Thailand. 2. Closing date desfoliation. Tropical Grassland 41:35-42.

Hare, M. D.; Wongpichet, K; Saengkham, M.; Thummasaeng, K. and Suriyajantratong, W. 2001. Juvenility and long-short day requirement in relation to flowering of Paspalum atratum in Thailand. Tropical Grasslands 35:139-143.

Hare, M. D.; Wongpichet, K.; Tatsapong, P.; Norksombat, S. and Saenghum, M. 1999. Method of seed harvest, closing date and height of closing cut affect seed yield and component in Paspalum atratum in Thailand. Tropical Grassland 33:83-90.

Humphreys, L. R. and Riveros, F. 1986. Tropical pasture seed production, plant production and protection paper $n .^{\circ} 8$. FAO, Roma.

Jornada, J. B. J.; Medeiros, R. B.; Pedroso, C. E. S.; Saibro, J. C. and Silva, M. A. 2005. Efeito da irrigação, épocas de corte da forragem e doses de nitrogênio sobre o rendimento de sementes de milheto. Revista Brasileira de Sementes 27:50-58.

Lopes, R. R. and Franke, L. B. 2011a. Correlação e análise do coeficiente de trilha dos componentes do rendimento de sementes de grama-forquilha. Revista Brasileira Zootecnia 40:972-977.

Lopes, R. R. and Franke, L. B. 2011b. Produção de sementes de quatro ecótipos de Paspalum nativos do Rio Grande do Sul. Revista Brasileira de Zootecnia 40:20-30.

Maguire, J. D. 1962. Speed of germination-aid in selection and evaluation for seedlig emergence and vigor. Crop Science 2:176-177.

MAPA - Ministério da Agricultura, Pecuária e Abastecimento. 2008. Instrução normativa $\mathrm{n}^{\circ} 30$. Normas e padrões para produção e comercialização de sementes de espécies forrageiras de clima tropical. Available at: <http:www.mapa.gov.br>. Accessed on: Nov. 10, 2015.

Martiniello, P. 2008. Adaptability of bermudagrass turf varieties to a Mediterranean environment. The European Journal of Plant Science and Biotechnology 2:74-81.

Martiniello, P. and Silva, J. A. T. 2011. Physiological and bioagronomical aspects involved in growth and yield components of cultivated forage species in mediterranean environments: a review. The European Journal of Plant Science and Biotechnology 5:64-68.

Meirelles, P. R. L.; Batista, L. A. R.; Costa, C.; Silva, M. G. B.; Factori, M. A.; Silveira, J. P. F. and Cavasano, F. A. 2013. Germoplasma do gênero Paspalum com potencial para produção de forragem. Bioscience Journal 29:1587-1595.

Moore, K. J.; Boote, K. J. and Sanderson, M. A. 2004. Physiology and developmental morphology. p.179-215. In: Warm-season $\left(\mathrm{C}_{4}\right)$ grasses. Moser, L. E.; Burson, L. and Sollenberger, E., eds. American Society of Agronomy, Madison.

Munhoz, R. E. F.; Zonetti, P. C. and Roman, S. 2009. Superação da dormência em sementes e desenvolvimento inicial em Brachiaria brizantha cv. MG5 através da escarificação com ácido sulfúrico. Revista em Agronegócios e Meio Ambiente 2:55-67.

Nakagawa, J. 2014. Os componentes da produtividade de sementes. Informativo Abrates 24:15-21.

Ohlson, O. C.; Souza, C. R.; Gvazza, M. I. A. and Panobianco, M. 2009. Qualidade física e fisiológica de sementes de Brachiaria brizantha comercializadas no estado do Paraná. Informativo Abrates 19:37-41.

Pereira, E. A.; Barros, T.; Volkmann, G. K.; Battisti, G. K.; Silva, J. A. G.; Simioni, C. and Dall'Agnol, M. 2012. Variabilidade genética de caracteres forrageiros em Paspalum. Pesquisa Agropecuária Brasileira 47:1533-1540.

Pinto, J. C. 1982. Nitrogênio e métodos de semeadura no rendimento de sementes de Paspalum guenoarum Arech. Dissertação (M.Sc.). Universidade Federal do Rio Grande do Sul. Rio Grande do Sul, Porto Alegre.

Quadros, D. G.; Oliveira, G. C.; Oliveira, E. P.; Andrade, A. P.; Silva, A. V. and Stolben, E. 2010. Componentes da produção de sementes de duas cultivares de Brachiaria brizantha (Hochst. ex A. Rich.) Stapf nos cerrados da Bahia. Revista Científica de Produção Animal 12:19-22.

Sadras, V. O. and Slafer, G. A. 2012. Environmental modulation of yield components in cereals: heritabilities reveal a hierarchy of phenotypic plasticities. Field Crops Research 127:215-224.

Scheffer-Basso, S. M.; Trentini, V. and Barea, K. 2007. Manejo de Paspalum dilatatum Poir. biótipo Virasoro. 2. Produção de sementes. Revista Brasileira de Zootecnia 36:1022-1028.

Skerman, P. J. and Riveros, F. 1992. Graminea tropicales. FAO, Roma.

Souza, F. H. D. 2001. Produção de gramíneas forrageiras tropicais. Embrapa, São Carlos.

West, S. H. and Pitman, W. D. 2001. Seed production technology of tropical forrages. p.143-166. In: Tropical forage plants, development and use. Sotomayor-Ríos, A. and Pitman, W. D., eds. CRC Press, Florida. 